\title{
Da lágrima à resistência: o clamor ético das vítimas e a potência política do rosto exposto como imagem
}

\author{
Frederico Vieira \& Ricardo Lessa Filho*
}

Resumo: O presente artigo resulta de uma tentativa de aproximar e refletir sobre alguns conceitos do pensamento de Lévinas, Butler e Barthes para uma visada política das imagens, especialmente daquelas que expõem rostos e corpos vitimados por violências. Para tanto, nos debruçamos sobre uma perspectiva ética da análise de retratos, considerando a potência política que o revisitar do sofrimento das vítimas da ditadura civil-militar brasileira podem espicaçar em nós. O filme documental Retratos de identificação nos fornece dois mugshots dos rostos de Chael Charles Schreier e Maria Auxiliadora Lara Barcelos, a Dora, duas jovens vítimas daquele regime exceção. Ao elegermos esses dois registros fotográficos, expusemo-los à reflexão desenvolvida pelos referidos filósofos, para que pudéssemos como se compreender as dimensões política e ética das imagens desses dois rostos violados, contudo inescapáveis.

Palavras-chave: rosto; vida precária; ética; ditadura militar brasileira; mugshots.

Resumen: El presente artículo resulta de una tentativa de aproximación y reflexión sobre algunos conceptos del pensamiento de Lévinas, Butler y Barthes para una ambicionada política de las imágenes, especialmente de aquellas que exponen rostros y cuerpos víctimas de violencia. Para ello, nos concentramos en una perspectiva ética del análisis de retratos, considerando el potencial político que la revisión del sufrimiento de las víctimas de la dictadura civil-militar brasileña puede espolear en nosotros. La película documental Retratos de identificação nos proporciona dos mugshots de los rostros de Chael Charles Schreier y Maria Auxiliadora Lara Barcelos, Dora, dos jóvenes víctimas de aquel régimen de excepción. Al elegir estos dos registros fotográficos, los expusimos a la reflexión desarrollada por los antedichos filósofos para poder aprehender las dimensiones política y ética de las imágenes de esos dos rostros violados, pero ineludibles.

Palabras clave: rostro; vida precaria; ética; dictadura militar brasileña; mugshots.

Abstract: The present article results from an attempt to approach and reflect on some concepts of the thought of Lévinas, Butler and Barthes for a political view of images, especially those that expose faces and bodies victimized by violence. To do so, we focus on an ethical perspective of portraiture, considering the political power that revisits the suffering of the victims of the Brazilian civil-military dictatorship may spur

* Frederico Vieira: Universidade Federal de Minas Gerais - UFMG, Faculdade de Filosofia e Ciências Humanas, Programa de Pós-graduação em Comunicação. 31270-901, Belo Horizonte, Minas Gerais, Brasil.

E-mail: frederico.vieira.souza@gmail.com

Ricardo Lessa Filho: Doutorando. Universidade Federal de Pernambuco - UFPE, Centro de Artes e Comunicação, Programa de Pós-Graduação em Comunicação. 50670-901, Recife, Brasil. E-mail: ricardolessafilho@ hotmail.com

Submissão do artigo: 22 de outubro de 2018. Notificação de aceitação: 22 de janeiro de 2019 .

Doc On-line, n. 25, março de 2019, www.doc.ubi.pt, pp. 64-81. 
us on. The documentary film Retratos de identificação provides us with two mugshots of the faces of Chael Charles Schreier and Maria Auxiliadora Lara Barcelos, the Dora, two young victims of that exceptional regime. In electing these two photographic records, we exposed them to the reflection developed by the said philosophers, so that we could understand the political and ethical dimensions of the images of these two violated but inescapable faces.

Keywords: face; precarious life; ethics; brazilian military dictatorship; mugshots.

Résumé : Le présent article est le résultat d'une tentative d'approche et de réflexion sur certains concepts de la pensée de Lévinas, Butler et Barthes pour élaborer une vision politique des images, en particulier celles qui exposent des visages et des corps victimes de violence. Pour ce faire, nous nous concentrons sur une perspective éthique du portrait, compte tenu du pouvoir politique susceptible de rappeler les souffrances des victimes de la dictature civilo-militaire brésilienne. Le film documentaire Retratos de identificação nous fournit deux clichés du visage de Chael Charles Schreier et de Maria Auxiliadora Lara Barcelos, la Dora, deux jeunes victimes de ce régime exceptionnel. En choisissant ces deux enregistrements photographiques, nous les avons confrontés à la réflexion développée par lesdits philosophes, afin de pouvoir comprendre les dimensions politiques et éthiques des images de ces deux visages violés, mais incontournables.

Mots-clés : visage ; vie précaire ; éthique ; dictature militaire brésilienne ; mugshots.

Quando um rosto violentado é exposto em um retrato, como seu apelo ético a nós pode dizer de um sofrimento coletivo, que nos ultrapassa no que é visto e que anuncia um por vir da política? De que forma uma exposição mortificadora do corpo pode, outramente e também, denunciar uma resistência incapturável dos sujeitos que fizeram face ao silenciamento dos direitos perpetrados por um estado de exceção? À procura de respostas para tais indagações e, para além disso, no esforço de re-dizer não matarás aos que persistem em defender ideias e práticas violentas, fascistas, discutimos nesse artigo conceitos caros a uma compreensão política das imagens a partir de uma visada ética.

Na primeira parte, apresentamos conceitos de Rosto, Vida Precária e Resistências a partir do pensamento de E. Lévinas e J. Butler, com vistas a discutir a relação entre as imagens de vítimas de violências e a demanda ética exposta pelo dizer dos rostos/corpos nelas retratados. Se as imagens falam, em que medida o silenciamento delas pode operar uma violência política sobre a memória das vítimas?

Com o intuito de apontar caminhos para respostas, trouxemos na segunda parte do texto uma análise a respeito de Retratos de Identificação ${ }^{1}$, elegendo os retratos de dois presos políticos vítimas de torturas e mortos pela ditadura

1. Retratos de identificação, filme brasileiro de Anita Leandro, realizado em 2014, duração de $73 \mathrm{~min}$. 
civil-militar brasileira. Nessa análise, consideramos também as noções barthesianas de punctum e de tempo mortificado que nos auxiliam na compreensão do sofrimento indizível de Chael e Dora.

No mesmo sentido de revisitar a dignidade desses dois jovens feitos imagens apesar de tudo, vamos atualizar o gesto de resistir pela memória que nos ronda historicamente, aproximando-nos temporalmente daquilo que aparentemente nos divide, reafirmando a singularidade de rostos/corpos até então relegados ao apagamento, a um anonimato duplamente vil: seja pela violência concreta que as torturas físicas, psicológicas ou morais causaram, seja pela eliminação ética que os vestígios fotográficos (e também políticos) teimam em não consumar ${ }^{2}$.

\section{Rostos, vidas precárias e resistências}

Um dos mais conhecidos conceitos, trabalhado exaustivamente por Lévinas ao longo de sua obra, é o de rosto, o qual merece constante atenção do filósofo desde Totalidade e Infinito (1961) até suas últimas entrevistas. Por meio do rosto, o pensador procura abordar importantes aspectos éticos que constituem nossa própria humanidade, na qual outrem me antecede e de cujas alteridades não posso escapar. Por reconhecer a complexidade do conceito e a impossibilidade de sintetizá-lo tão brevemente nesse artigo, destacamos alguns aspectos essenciais.

2. Os autores escreveram esse texto em outubro de 2018 , às vésperas do segundo turno da eleição presidencial brasileira, em que disputaram o cargo dois candidatos: Fernando Haddad, do Partido dos Trabalhadores; e Jair Bolsonaro, do Partido Social Liberal. O primeiro, da cena política de esquerda, apresentou, entre outros, um projeto de continuidade das políticas sócio-econômicas adotadas pelos governos anteriores de Lula (2003-2006 e 2007-2010); e de Dilma Rousseff (2011-2014 e 2015-2016), ambos do mesmo partido. O segundo candidato, à extrema direita conservadora, prometeu recuperar a moral e os bons costumes, a partir de ações políticas calcadas em condutas fascistas e de fortes feições milicianas. Jair Bolsonaro foi eleito presidente com 57,8 milhões de votos. Após a Constituição Cidadã de 1988, a jovem democracia brasileira tem um militar da reserva comando do país, juntamente com seu vice, general do Exército Brasileiro. Durante todo o período da campanha eleitoral de 2018, entidades, movimentos sociais e instituições democráticas defensoras dos direitos humanos se manifestaram contra a legitimação nas urnas de um candidato a presidente como Jair Bolsonaro. Já nas primeiras semanas de seu governo medidas questionáveis foram tomadas, das quais duas podem ser citadas como exemplares: assinou decreto que facilita a posse de armas de fogo, que modifica um decreto de 2004, o qual regulamentou o Estatuto do Desarmamento; a assinatura de um segundo decreto que mudou a regulamentação da Lei de Acesso à Informação (LAI), para permitir que cargos comissionados - muitos sem vínculo permanente com a administração pública - possam classificar informações oficiais com o grau máximo de sigilo: de 25 anos (dados ultrassecretos) ou 15 anos (dados secretos). Na prática, isso ampliará o número de documentos sigilosos, algo criticado pelas entidades e especialistas no tema. Ressalta-se ainda que é comum, por exemplo, que o presidente da república, Jair Bolsonaro, renda, e sem nenhum constrangimento, elogios públicos a torturadores, militares criminosos e anistiados, responsáveis por inúmeras mortes e desaparecimentos de presos políticos como Chael e Dora durante o regime civil-militar brasileiro. 
Rompendo com o reino do mesmo, nem fenômeno, nem substância, para Lévinas o rosto torna nu o homem; não a nudez da neutralidade esvaziada de sentido, mas de um clamor ético; faz do homem ente exposto e vulnerável. Nas palavras de Lévinas:

O modo como o Outro se apresenta, ultrapassada a ideia do Outro em mim, chamamo-lo, de facto, Rosto. Esta maneira não consiste em figurar como tema sob o meu olhar, em expor-se como um conjunto de qualidades que formam uma imagem. O rosto de Outrem destrói em cada instante e ultrapassa a imagem plástica que ele me deixa, a ideia à minha medida e à medida do seu ideatum - a ideia adequada. Não se manifesta por essas qualidades, mas kath'autò. Exprime-se. O rosto, contra a ontologia contemporânea, traz uma noção de verdade que não é o desvendar de um Neutro impessoal, mas uma expressão (Lévinas, 1980: 37-38).

Portanto para Lévinas a expressividade do rosto ultrapassa a imagem plástica que possamos lhe atribuir, embora o rosto ofereça tal imagem como um resto da desconstrução que promove em sua passagem pela expressão liberta da neutralidade e do anonimato.

Vieira e Marques (2016) lembram, em suas análises a respeito das reflexões feitas por Lévinas $(1982,2007)$, que o conceito de rosto é definido como o que nos afasta de nós mesmos ao conduzir-nos pelo labirinto da alteridade. "Não é propriamente a face humana, mas um vestígio da presença de um Outro que, por mais que esteja próximo, mantém-se à distância" (Vieira e Marques, 2016: 18).

Assim, o rosto levinasiano deve ser entendido para além da manifestação concreta da face humana, podendo se expressar muitas vezes em caráter indicial no rosto concreto, mas apontando para as múltiplas formas das alteridades; ao mesmo tempo em que o vejo, o rosto não se deixa reduzir às denominações do percebido. Portanto, ele não é uma simples oferta de dados: é o que comunica sem se deixar apreender como representação.

Sua presença consiste em se despir da forma que, entrementes, já a manifestava. Sua manifestação é um excedente (surplus) sobre a paralisia inevitável da manifestação. É precisamente isto que descrevemos pela fórmula: o rosto fala. A manifestação do rosto é o primeiro discurso. Falar é, antes de tudo, este modo de chegar por detrás de sua aparência, por detrás de sua forma, uma abertura na abertura (Lévinas, 1993: 59)..

Em outras palavras, o rosto vocaliza, mas não por meio das palavras comuns e sim através de algo que as antecede. Esse apontamento evidencia com clareza os mecanismos de interlocução e, portanto, discursivos que perpassam o conceito de rosto, o que o torna radicalmente um conceito comunicativo.

Para Lévinas, em Totalidade e Infinito, a linguagem ética do rosto se estrutura como discurso, em que outrem só pode me falar a partir de uma diferença 
absoluta, por sua alteridade inviolável. Precedendo o Outro, o discurso não tem como ponto de partida a consciência. Ele reside nas infinitas possibilidades de outrem, o que se define como Infinito. Diante disso, o eu se vê sem poderes, já que ele não pode incorporá-lo a si. A estrutura do Infinito é ética; somente ao matar outrem, no assassínio, seria impossível apagar o Infinito que se apresenta por meio do rosto (Lévinas, 1988: 177). Daí o mandamento ético que emana do rosto: Não matarás! E perante outrem eu me vejo em minha violência de existir, já que posso destruí-lo.

Na maturidade de seu pensar, em De outro modo que ser, Lévinas (2011) passa a dizer o sujeito a partir de sua vulnerabilidade e o rosto deixa o campo da fruição, privilegiado na discussão contida em Totalidade e Infinito, para padecer de sua corporalidade radical, rosto como corpo. Na proximidade do corpo, se dá o encontro efetivo de carne e sangue. Carrara (2010) considera que a abordagem tardia de Lévinas reafirma a intuição presente no início de sua trajetória filosófica: "a identidade do sujeito não vem dele mesmo, mas de sua interpelação pelo Outro. Ele é para o outro. O um-para-o-outro da responsabilidade infinita se oferece como significância que fundamenta sua existência [...]" (Carrara, 2010: 83). Nas palavras de Lévinas: "A subjetividade do sujeito é a vulnerabilidade, exposição à afeição, sensibilidade, passividade mais passiva, tempo irrecuperável, dia-cronia inssemelhável da paciência, exposição sempre a expor, exposição a exprimir, e assim ao Dizer, e assim ao Dar" (Lévinas, 1999a: 85).

Butler (2011, 2015a, 2015b, 2017, 2018) tem retomado a filosofia levinasiana em suas últimas obras para sustentar a perspectiva ética que nos impõe uma responsabilidade primeira por outrem, inescapável à nossa própria condição. $\mathrm{Na}$ esteira de seu pensamento, Butler desenvolve a noção de vida precária, a qual faz, de certo modo, borrar os limites eu-outrem, alertando para nossa mútua dependência e compartilhamento da mesma precariedade da vida humana.

O corpo está exposto a forças articuladas social e politicamente, bem como a exigências de sociabilidade - incluindo a linguagem, o trabalho e o desejo -, que tornam a subsistência e a prosperidade dos corpos possíveis. A concepção mais ou menos existencial da "precariedade" está, assim ligada à noção mais especificamente política da "condição precária". (Butler, 2015a: p. 16).

Se para Lévinas (1980: 37-38) o rosto torna nu o homem, é porque exige de sua própria nudez - de sua exposição absoluta - um clamor ético. A própria exposição do rosto torna-se também um gesto precário.

Vida precária é uma tentativa de aproximação à questão de uma ética da não violência, baseada na compreensão de quão fácil é eliminar a vida humana. Emmanuel Lévinas oferece uma concepção da ética baseada na apreensão da precariedade da vida, que começa com a vida precária do Outro. Lévinas 
usa o "rosto" como figura que comunica tanto a precariedade da vida como a interdição da violência. Deste modo, proporciona-nos uma via para compreender como a agressão não é distante de uma ética da não violência; a agressão constitui a matéria mesma do debate ético. Lévinas leva em consideração o temor e a angústia que a agressão trata de negar, mas argumenta que a ética é precisamente uma luta para evitar que o temor e a angústia se convertam em um gesto assassino. Ainda que sua concepção teológica evoca uma cena entre dois seres humanos confrontados, cada um dos quais é o portador de um rosto que pronuncia uma pergunta ética a partir de uma origem aparentemente divina, seu ponto de vista é sem dúvida útil para uma análise cultural que trata de descrever a melhor maneira possível o humano, a dor e o sofrimento, e de admitir do melhor modo possível nas representações públicas os "rostos" daqueles contra quem se dirige a violência (Butler, 2006: 20).

Butler aponta para a ética primeira que escapa dos domínios da ontologia, tema caro a Lévinas; o que se constata é que, via resistência pelo que difere, mesmo que seja do meu desejo estar o mais distante possível do que defino e imagino como uma forma de vida abjeta ou não-desejável, o reforço dos recursos discursivos distintivos podem me capturar, em parte como um sintoma da negação à proximidade, em parte como recusa à minha própria precariedade.

O aparecimento limitado e vivo do corpo é a condição de estar exposto ao outro; exposto à solicitação, à sedução, à paixão e ao dano; exposto de maneiras que nos sustentam, mas também a maneiras que podem nos destruir. Nesse sentido, a exposição do corpo aponta para a sua precariedade. Ao mesmo tempo, para Lévinas, esse ser precário e corporal é responsável pela vida do outro, o que significa que não importa o quanto alguém tema pela própria vida, preservar a vida do outro é fundamental (Butler, 2018: 121).

Butler (2011) também retorna ao conceito levinasiano de rosto para discutir o que os discursos produzidos pela circulação das imagens de vítimas das guerras nos territórios árabes têm revelado nesses tempos sombrios, em que poucos realmente sustentam as palavras que proferem e nos quais a ética democrática tem sido utilizada para justificar o uso da violência em legítima defesa, sobretudo por parte dos Estados Unidos e dos países aliados a eles. Muitas vezes somos implicados numa questão política, a da vida precária - tal como é o sofrimento nos rostos das vítimas árabes, das pessoas em situação de rua, dos povos indígenas em dizimação, da população LGBTI, entre tantos outros - mesmo que não o desejemos; antes mesmo que se forme em mim uma vontade de me implicar, o discurso verbo-visual que circula nas mídias, no espaço público me alcança e me interpela sobre isso.

De acordo com a obra Quadros de Guerra, para Butler, as imagens midiatizadas da guerra conformam os rostos dos árabes, capturam-nos etnocentricamente e esvaziam suas possibilidades de significação, emoldurando-os de 
acordo com o olhar ocidentalizante. Essa precariedade da imagem ao mesmo tempo em que revela uma forma de vida, impossibilita que o outro fale como totalmente outro; o sofrimento de outrem é dito, falado, representado tal e qual eu desejo ouvir, o que per se constitui uma violência. Isso é ainda mais claro se considerarmos que sempre haverá o outro de outrem, os rostos dos terceiros.

Em seus ensaios recentes, a autora ainda se pergunta qual seria a relação entre precariedade e vulnerabilidade. Em princípio ela esclarece que Lévinas, ao afirmar que somos em algum sentido responsáveis por aquilo que nos oprime, não quer dizer que causamos nossa opressão. O filósofo entende "opressão" como aquilo que, a despeito de nossa vontade, os outros reivindicam de nós e que, ao sermos chamados a respondê-los, isso se dá muitas vezes de forma imprevisível, violenta e para qual não estamos preparados. "Em outras palavras, você pode me amedrontar e me ameaçar, mas a minha obrigação [ética] em relação a você deve permanecer firme" (Butler, 2018: 122).

A responsabilidade ética pressupõe, portanto, a capacidade de resposta, também ética; se somos a priori vulneráveis uns aos outros, a precarização imposta a mim ou a outrem por quaisquer tipos ou meios de opressão me concerne, posto que compartilhamos dessa dependência inscrita nos (e constitutiva dos) nossos corpos.

[...] aquele rosto olhando em direção a mim, em sua expressão - em sua mortalidade - convoca-me, demanda-me, ordena-me: como se a morte invisível enfrentada pelo rosto do outro [...] fosse um problema meu. Como se, desconhecido pelo outro que já, na nudez de seu rosto, ele afeta, ele me reportasse antes mesmo de confrontar-se comigo, antes de se tornar a morte que me encara, a mim mesmo, face a face. A morte do outro homem coloca-me sob pressão, chama-me à responsabilidade, como se eu, pela minha possível indiferença, tornasse-me cúmplice daquela morte, invisível ao outro que é exposto a ela; como se mesmo antes de ser condenado, tivesse que responder pela morte do outro, e não deixá-lo só em sua solidão mórbida. (Lévinas, 1999a: 24-25).

Para Lévinas a ética assume o lugar de filosofia primeira, é anterior à política e sobre ela produz atravessamentos, sobretudo antecipando o lugar de outrem em relação aos interesses do Uno, seja do eu individual ou do todo estatal. Não uma ética normativa, mas ligada ao que antecede qualquer possibilidade de discurso. E tal visão é incômoda já que atua sobre certa intraduzibilidade política da ética.

Para Bensussan (2009), é exatamente esse ponto que se constitui elementochave de um pensamento - ou para um pensamento do político - que se pode encontrar em Lévinas ou concluir de sua ética que, longe de se limitar a determinação de normas e condutas humanas, transcende os códigos em favor das singularidades e das diferenças subjetivas. 
Este princípio de intransitividade não é certamente um consentimento dado ao pensamento de uma política. Um pensamento do e da política é, ao contrário, fortemente requisitado pela ideia de uma "entrada" dos terceiros na política. Mesmo que não haja em Lévinas uma filosofia política, não há um apoliticismo. A radicalidade "antipolítica" do pensamento levinasiano do político procede de uma desilusão da política, da constatação de um desencantamento de seus poderes que, no entanto, não são acompanhados, de uma resignação ou de uma despolitização do pensamento e da ética. (Bensussan, 2009: 51)

Em nosso entender, Butler trabalha justamente nos limites dessa intransitividade levinasiana quando estabelece um avizinhamento entre a vulnerabilidade e o agir político. Seus questionamentos nos fazem entender os corpos como uma centralidade do processo comunicativo daquilo/daqueles que vêm a público e que, portanto, tomam corpo publicamente para expor via fragilidade dos rostos/corpos sua força política.

A conjunção entre os rostos precários/precarizados em movimento de resistência aos contextos de opressão, torna evidente como a vulnerabilidade se torna uma espécie de ponto de origem para a conformação dos públicos, dos terceiros, dos outros do outro; da exposição pública das questões de interesse público e da comunicação decorrente dessa articulação coletiva. Butler promove uma reflexão a esse respeito, trazendo a responsabilidade ética pensada por Lévinas ao seio da política, sendo a corporalidade um vetor para viabilizar essa importante aproximação.

Para a autora, haveria uma simultaneidade entre ser precário/precarizado e agir. Butler (2018) lembra que a resistência dos sujeitos expostos a violências de toda ordem não se traduz como a vitória da força sobre a vulnerabilidade; a força não corresponde ao oposto dessa, mas a vulnerabilidade pode ser mobilizada não somente como estratégia individual e sim coletivamente.

De certa maneira, a reunião coletiva dos corpos em assembleia é um exercício da vontade popular, a ocupação e a tomada de uma rua que parece pertencer a outro público, uma apropriação da pavimentação com o objetivo de agir e discursar que pressiona contra os limites da condição de ser reconhecido em sociedade. Mas as ruas e a praça não são a única maneira de as pessoas se reunirem em assembleia, e sabemos que uma rede social produz ligações de solidariedade que podem ser bastante impressionantes e efetivas no domínio virtual. (Butler, 2018: 167).

Sem dúvidas, muitas são as formas de agir em resistência, de lutar politicamente contra a opressão, valorizando sobretudo a comunicação que denuncia e expõe a violência. Dentre essas formas, Butler (2018) analisa a resistência não violenta que, numa perspectiva levinasiana, seria justamente aquela que considera a reivindicação ética e a responsabilidade por outrem como fundamento 
da ação. Ela ainda destaca o aspecto performativo que os corpos assumem nesse contexto e a ruptura dos corpos com os termos da violência.

A resistência não violenta exige um corpo que aparece, que age, e que em sua ação busca constituir um mundo diferente daquele que encontrou, o que significa confrontar a violência sem reproduzir os seus termos. A não violência não consiste em apenas dizer não a um mundo violento, mas trabalha o eu $\mathrm{e}$ sua relação com o mundo de maneira nova, buscando corporificar, ainda que de maneira provisória, a alternativa pela qual luta. Podemos então dizer que a resistência não violenta é performativa? (Butler, 2018: 204, grifo nosso).

Sem dúvidas respondemos sim à provocação da autora. O que veremos, adiante, é como essa intrincada relação entre rosto, vulnerabilidade e resistência pode se expressar nas imagens, seja pelo que elas nos apresentam ou por aqui que elas dizem. Ambos os gestos performam uma inescapável resistência do rosto/corpo que, a despeito de toda violência, desvia-se da captura. Os retratos de prisioneiros (mugshots) falam até hoje de um sofrimento que nos concerne em nossa responsabilidade ética, na infinita expressão das vítimas da ditadura civil-militar no Brasil. Numa palavra, na face, reconheço vestígios que, captados pelo olhar, formulam uma espécie de interpelação ética a nós; somos intimados a uma resposta, ao acolhimento de outrem, totalmente distinto de mim; somos chamados à responsabilidade, não somente sobre o que fazemos, mas também diante do mal que lhe venham infligir. Perante o rosto, a legítima defesa é para sempre atravessada pelo imperativo "não matarás".

\section{Retratos de identificação: a perpetração da violência militar no rosto}

A partir das hipóteses sobre o rosto defendidas por Lévinas e da precariedade da vida postulada por Butler, o artigo buscará, agora, sondar através dos mugshots de Retratos de identificação ${ }^{3}$ (Anita Leandro, 2014) o vestígio particular de dois rostos humanos presentes nesta obra cinematográfica. Dois rostos profundamente violentados, depauperados, expelidos, por assim dizer, da própria vida a partir das violências perpetradas pela ditadura civil-militar brasileira (1964-1985). Desta maneira, os rostos de Chael Charles Schreier e Maria Auxiliadora Lara Barcelos, a Dora, servirão como vias aproximativas entre a imagem - aquilo que a faz sobreviver no tempo - e a ideia de uma rostidade humana sempre tão próxima - por sua inermidade, por sua fragilidade intrínsecas - à desaparição, ao sofrimento sem nome.

3. Durante a ditadura civil-militar, presos políticos eram fotografados em diferentes situações: investigações, interrogatórios, exames de corpo de delito, processos de banimento, inquéritos policiais militares e necropsias. Confrontadas ao testemunho de sobreviventes, essas fotografias, tiradas com o objetivo de controle dos prisioneiros, ressurgem no filme documental Retratos de identificação. 
Em um célebre livro de 1980 (e o último publicado em vida), Roland Barthes propõe a ideia de algo terrível que existe em toda fotografia: "o retorno do morto" (Barthes, 1984: 20). Para o autor francês, a fotografia revelaria sempiternamente alguma coisa sobre uma morte já anunciada que somente o registro fotográfico poderia capturar, pois o que uma foto captura é sempre uma parcela do tempo já irrepetível, de um corpo - e de um rosto - que cedo ou tarde tornar-se-á cadáver. Ao mesmo tempo que elabora uma ideia da mortidade em todo ato fotográfico (o tempo congelado é, também, o tempo mortificado em sua própria eternidade), Barthes insiste naquilo que viria a ser em A câmara clara, sua proposta teórica mais valiosa e de maior destaque: o punctum.

Dessa vez, não sou eu que vou buscá-lo [...], é ele que parte da cena, como uma flecha, e vem me transpassar. Em latim existe uma palavra para designar essa ferida, essa picada, essa marca feita por um instrumento pontudo; essa palavra me serviria em especial na medida em que remete também à ideia de pontuação e em que as fotos de que falo são, de fato, como que pontuadas, às vezes até mesmo mosqueadas, com esses pontos sensíveis; essas marcas, essas feridas são precisamente pontos. [...] pois punctum é também picada, pequeno buraco, pequena mancha, pequeno corte - e também lance de dados. O punctum de uma foto é esse acaso que, nela, me punge (mas também me mortifica, me fere) (Barthes, 1984: 46).

Em 1981 coube a Jacques Derrida, num texto direcionado ao seu grande amigo já morto, aprofundar a compreensão do punctum - e neste aprofundamento teórico, avizinhar de maneira preciosa (gesto que Barthes não viveu suficientemente para realizar) o punctum da alteridade, isto é, do detalhe do Outro que a partir de uma imagem sobrevive em mim, em nós:

Punctum traduz ademais, em La chambre Claire, um valor à palavra "detalhe": um ponto de singularidade que penetra a superfície da reprodução e inclusive da produção, das analogias, das semelhanças, dos códigos. Essa singularidade penetrada me alcança de um golpe, me fere ou me assassina e, em princípio, parece olhar diretamente para mim. Está em sua definição aquilo que se dirigia a mim. A mim se dirige a singularidade absoluta do outro, o Referente cuja imagem própria eu não posso suspender mesmo quando sua "presença" se oculta para sempre [...], quando ele se encontra fundido já, enquanto passado. A mim, se encaminha também a solidão que desfaz a trama do mesmo, as redes ou os ardis da economia. Porém, é sempre a singularidade do outro, lugar que incide em mim sem dirigir-se a mim, sem que esteja presente em mim e o outro possa ser eu; eu antes de ter sido ou, tendo sido, eu morto agora, no futuro anterior ou no passado anterior da fotografia. Em meu nome, acrescentarei. Mesmo que, como sempre, pareça ligeiramente marcada. (Derrida, 2008: 274-275).

Então se o punctum é o detalhe de uma foto que pulsa diante de nós por sua dor desmesurada, por sua mancha outrora inaparente agora revelada 
-, este detalhe, este vestígio pulsa por causa da potência (puissance) que a imagem porta toda vez que ela é capaz de atravessar o tempo e vir nos tocar. Esta travessia (este punctum), portanto, é sempre um acontecimento picado, esburacado, pungido. E não é sobre uma fissura da dor que o mugshot frontal de Chael Charles Schreier (FIG. 1), justamente, emerge da escuridão - ali onde esta imagem outrora soterrada nos arquivos da ditadura pôde, por sua potência, fazer-se visível aos nossos olhos, ao nosso mundo visual para clamar por uma história mais verdadeira de seu próprio sofrimento - e vem nos tocar, ou melhor, nos ferir, nos pungir?

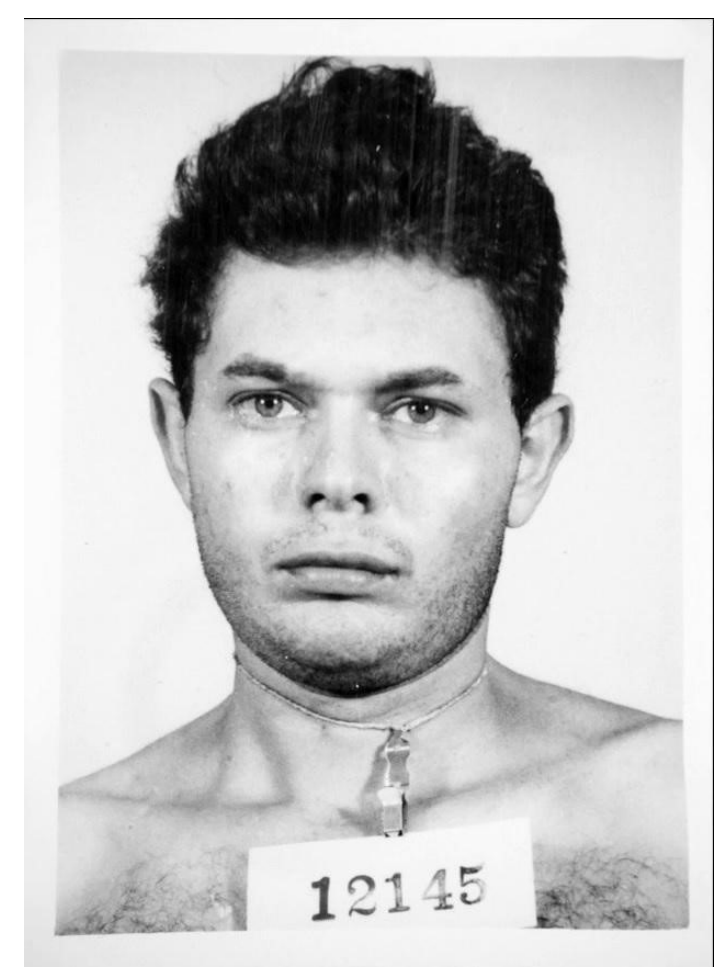

Figura 1. O mugshot de Chael Charles Schreier.

Pouco tempo depois do registro de seu mugshot, o rosto/corpo que exerceu um gesto de resistência, sofreu um ato de aniquilação. Chael Schreier mediante a um regime radical, antes de ser encarcerado e torturado decide comer somente uma única folha de alface e beber dois copos d'água por dia durante seu período como foragido da ditadura civil-militar e em algumas semanas perde algo em torno de 40 quilos - a resistência que em Chael se dá através da degradação do próprio corpo como a única resposta corpórea possível aos 
torturadores. Ato de aniquilação: com o seu corpo fragilizado pela falta de nutrientes e principalmente pelos constantes "espancamentos, chutes, sevícias sexuais e choques elétricos" (Leandro, 2016: 112), Chael não resiste a um dia e uma noite de torturas na Vila Militar e vem a falecer.

Nos olhos marejados de Chael - este olhar que já parecia prenunciar sua própria morte -, alguma coisa dilacera simplesmente a materialidade da imagem. Dilacera porque abre o tempo, e tudo só pode ser verdadeiramente aberto se antes for tocado - uma caixa de papelão jamais poderá ser aberta somente através do desejo para que ela se abra. Então o rosto de Chael nos fere (como punctum), nos comove (como alteridade) ali mesmo onde sua resistência faz emergir em seu olhar a dor expectorada da violência e da humilhação exercida pelos militares. Este mugshot deixa transparecer toda a vulnerabilidade de seu rosto, do som que provém dele, daquilo que o atravessa em sua agonia, em seu sofrimento (Butler, 2006: 168).

Deste rosto nu, desta violência exercida contra esta face, uma insuportável vulnerabilidade ficou exposta: "o problema da vulnerabilidade original a respeito do outro - uma vulnerabilidade que não se pode ignorar sem deixar de ser humano" (Butler, 2006: 14).

A foto do rosto de Chael, esta coisa já torturada, já humilhada, já despedaçada em sua própria vida, atravessa o tempo (o ano de sua confecção pelos perpetradores da violência militar é o de 1969) para poder pousar diante de nosso olhar, isto é, para exigir de nós mesmos um novo olhar, para nos fazer perceber a nova e inadvertida legibilidade histórica que ele porta a partir da montagem que Anita Leandro exerce em Retratos de identificação: "falar da legibilidade das imagens não é somente dizer, de fato, que estas reclamam uma descrição (Beschreibung), uma construção discursiva (Beschriftung), uma restituição de sentido (Bedeutung)", mas que a montagem é capaz, escreve Georges Didi-Huberman, de conferir às imagens mesmas "sua legibilidade inadvertida" (Didi-Huberman, 2014: 17).

Dos quase cinquenta anos que separam a confecção do mugshot frontal de Chael do nosso presente, ao ser posto - pela montagem de Leandro - e exposto - pela sua precariedade, pela sua vulnerabilidade - diante de nós, esta rostidade humana parece exigir-nos um deciframento por tratar-se, justamente, de um documento histórico. E todo documento histórico - sejam os hieróglifos ou as imagens-arquivo, sejam as línguas indígenas ou os corpos dos povos alçado ao nosso presente não é outra coisa senão a possibilidade que temos de, custe o que custar, ler o tempo e ler as imagens onde o tempo tem uma oportunidade para ser decifrado: 
As imagens não nos dizem nada, mentem para nós ou são obscuras como hieróglifos enquanto alguém não se proponha ao incômodo de lê-las, é dizer, analisá-las, descompô-las, remontá-las, interpelá-las, distanciá-las fora dos "clichês linguísticos" que suscitam tantos "clichês visuais" (Didi-Huberman, 2008: 44).

\subsection{Lágrimas e expectoração}

Do mugshot de Maria Auxiliadora Lara Barcelos, a Dora (Fig. 2), emerge já aquilo que Lévinas escreve sobre o rosto que fala: "A manifestação do rosto é o primeiro discurso. Falar é, antes de tudo, este modo de chegar por detrás de sua aparência, por detrás de sua forma, uma abertura na abertura" (Lévinas, 1993: 59). Caso olhemos os traços do rosto de Dora nesta foto com atenção (ou seja, que olhemos por "detrás de sua aparência"), poderemos perceber a inscrição da dor vocalizada em sua fisionomia. Uma dor advinda da violência insular dos militares brasileiros, uma dor que é manifestada, justamente, naquilo que faz abrir o tempo - "uma abertura na abertura" -, isto é, que concede ao nosso presente um olhar outro às imagens do passado - a legibilidade histórica das imagens.

E neste olhar, neste gesto frágil e claudicante, o mugshot de Dora revelanos que a sua resistência (porque em sua fisionomia existe de fato uma força, um confrontamento sem dúvidas ao olhar da câmera fotográfica dos perpetradores) está inundada, marejada. As lágrimas de Dora - esta expectoração da dor que só pode ser exercida pelo rosto - é ao mesmo tempo o testemunho da violência sofrida por ela e de sua resistência - as lágrimas aparentemente contidas podem ser lidas, justamente, como uma resistência ao pranto absoluto, esparramado, suplicado que decerto deixaria os torturadores muito orgulhosos de seus atos perversos.

Mas esta representação não basta para explicar a força inesgotável desta imagem; nela toma corpo um segundo nível: o instante irrepetível de um choque de olhares; uma centelha que a registra, o ser que se descobre diante da câmera expressado em um gesto, consciente ou não, da vez derradeira em que foi fotografado, não para outra coisa senão para morrer. ${ }^{4}$ Por isso o ato fotográfico, sobretudo as imagens realizadas pelos perpetradores da violência, tem algo de performativo: mais do que descobrir um inimigo, cria-o; mais do que abrir uma ficha do detido, é a sua condenação à morte ou à tortura. A foto retrotrai, então, o instante, mas faz gravitar sobre ele tudo o que ocorrerá

4. Ao contrário de Chael que fora assassinado pelos militares, Dora cometera suicídio, devido aos traumas das torturas e humilhações de quando estava sob cárcere militar, saltando na frente de um trem no período de seu exílio político na Alemanha em 1976. 
posteriormente. Assim, poucas vezes a ideia barthesiana da fotografia como o "retorno do morto" foi tão precisa.

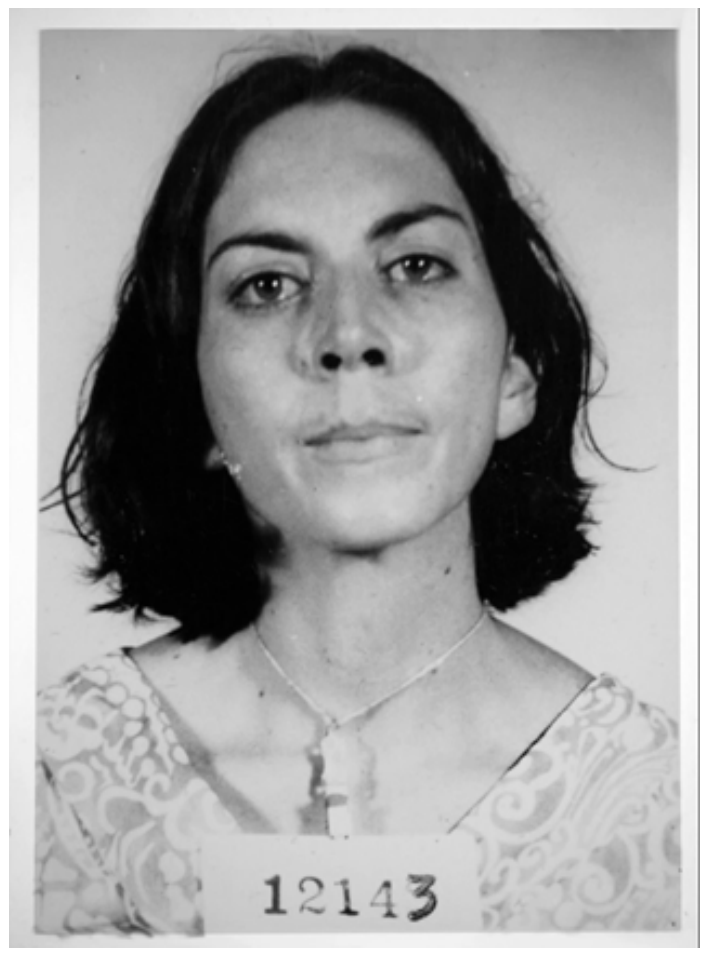

Figura 2. O mugshot de Maria Auxiliadora Lara Barcelos (Dora)

"Responder pelo rosto, compreender o que quer dizer, significa despertarse ao que é precário de outra vida, ou melhor, a precariedade da própria vida" (Butler, 2006: 169). Quando Judith Butler afirma que responder pelo rosto é despertar-se à própria vida precária, isso não incita-nos à luz da rostidade de Dora, uma rostidade que não pode ser somente rosto? Em seu mugshot seu olho direito ressuma, de maneira mais evidente que o olho oposto, o acúmulo da dor materializada em lágrimas, esta coisa já marejada que vertendo por sobre sua face é capturada, molhando sua bochecha direita, no momento irrefazível deste registro fotográfico. Mas há também na foto os cabelos emaranhados de Dora, à altura do pescoço, que desta maneira expõe nuamente a sua cerviz - e os cinco ou seis sinais epidérmicos existentes nela -, que amarrada a um fiapo de corda sustenta o seu número de registro carcerário e anuncia seu extermínio desde a prisão até o suicídio, em 1976. 
A morte do outro homem coloca-me sob pressão, chama-me à responsabilidade, como se eu, pela minha possível indiferença, tornasse-me cúmplice daquela morte, invisível ao outro que é exposto a ela; como se mesmo antes de ser condenado, tivesse que responder pela morte do outro, e não deixá-lo só em sua solidão mórbida. (Lévinas, 1999a: 24-25).

A cerviz de Dora que se expõe ao mesmo tempo pela violência da fotografia dos perpetradores (o autoritarismo da pose ideal, diríamos inclusive, a reificação do próprio gesto de posar) e pela vulnerabilidade de sua rostidade, uma rostidade que para Lévinas não se limita exclusivamente a um rosto humano (Butler, 2006: 20; Lévinas, 2011). Barthes (1984: 159) ainda em $A$ câmara clara fala que o ar de um rosto é indecomponível, e desta maneira a rostidade de Dora - tanto sua face como sua cerviz, tanto seu cabelo como seu vestido, tanto suas lágrimas como os seus sinais de pele - compele-nos à uma responsabilidade, à uma ética que em sua centelha de humanidade confronte toda indiferença, toda cumplicidade com a morte de outrem - ali mesmo onde sequer a morte poderá decompor o nosso desejo de memória, a nossa dor pelo Outro.

\section{Considerações finais}

As rostidades emergidas em Retratos de identificação parecem dizer que o conhecimento histórico não é outra coisa senão o ato de deslocar-se ao passado para descrevê-lo e recolhê-lo verdadeiramente tal como ele é. Talvez porque o conhecimento histórico não acontece senão a partir do agora, é dizer, de um estado de nossa experiência presente da qual emerge, por entre o imenso arquivo de textos, imagens ou testemunhos do passado, um momento de memória e legibilidade que surge como um ponto crítico, como um sintoma que desafia não somente o nosso presente, mas sobretudo a nossa História. Porque analisar as imagens do passado (ainda mais sendo um passado repressivo, totalitário) é como andar por uma ruína. Quase tudo está destruído, mas resta algo - uma folha de contato, uma imagem que resiste a toda fissura, uma legibilidade inadvertida exercida pela precariedade de uma vida, de um rosto. $\mathrm{O}$ importante é como nosso olhar põe essas imagens da ruína em movimento, e quem não sabe olhar - investigar - atravessa a ruína sem entender estas imagens e o seu gesto enlutado, ali onde todo o luto abre o tempo para que este seja trespassado, perscrutado.

Os rostos de Chael e Dora inscritos em seus respectivos mugshots de alguma maneira, retornados a existir a partir de sua aparição em Retratos de identificação, velam suas próprias vidas estilhaçadas pela violência ditatorial brasileira - ali onde somente o respeito e a memória podem, apesar de tudo, 
dignificar a morte. E se há uma morte dignificada, é porque ela se inscreve no nome mesmo (Chael, Dora), como se ao inscrever-se nestes dois epítetos (Chael, Dora) insinuasse uma resposta a muitas das outras vidas torturadas e assassinadas pela ditadura, mas jamais nomeadas, expostas, expectoradas ao nosso mundo visual e histórico.

Um rosto violentado exposto em um retrato nos impõe, por meio da autoridade de sua fragilidade, um dar-nos contas de um sofrimento que não é apenas deste ou daquele, mas de uma coletividade que nos ultrapassa entre o que é visto; rostos/corpos que anunciam um necessário por vir da política. A resistência incapturável dos rostos de Dora e Chael nos chega e fazem face ao silenciamento dos direitos perpetrados pela ditadura no Brasil. Urgente se faz revisitar a dignidade desses dois jovens feitos imagens apesar de tudo; atualizar o gesto de resistir pela memória, mesmo que precariamente, mesmo que mortalmente vulneráveis.

Das vidas precárias, dos rostos nus à luz de suas próprias vulnerabilidades, Chael e Dora demandam de nosso presente um desejo de lembrança, ali mesmo onde a memória como filigrana faz irromper nossa crônica mais obscura e cruel, como um punctum, como uma revelação outrora escondida - pois todo revelar-se carrega consigo uma introdução à ferida. Que estas duas imagens - em sua capacidade de migrar entre as temporalidades, em sobreviver apesar de tudo - incessantemente clamem pela "impaciência absoluta de um desejo de memória" (Derrida, 1994: 9), ali onde memória e luto convergem simultaneamente pelo reconhecimento histórico das vidas humanas assassinadas - como se ambos os gestos se apropriassem pelo tecido que eles mesmos dilaceram um sobre o outro -, já que a "impossibilidade do luto responde a impossibilidade do nascimento verdadeiro, pois somente o reconhecimento da morte permite a plenitude da vida" (Gagnebin, 2000: 110).

Graças ao filme de Anita Leandro, os rostos e as vidas de dois seres humanos foram dignificados malgrado tudo - e não sem falar sobre a dor, sobre os atos bárbaros que lhes foram infligidos. No fim, o abismo da história não nos divide, ronda-nos.

\section{Referências bibliográficas}

Barthes, R. (1984). A câmara clara: notas sobre a fotografia. Rio de Janeiro: Nova Fronteira.

Bensussan, G. (2009). Ética e experiência: a política em Lévinas. Passo Fundo: IFIBE.

Butler, J. (2004). Precarious Life: The Powers of Mourning and Violence. New York: Verso. 
Butler, J. (2006). Vida precaria: el poder del duelo e la violência. Buenos Aires: Paidós.

Butler, J. (2011). Vida precária. Contemporânea - Revista de Sociologia da UFSCar, n.1: 13-33. São Carlos, Departamento e Programa de PósGraduação em Sociologia da UFSCar.

Butler, J. (2015a). Quadros de guerra: quando a vida é passivel de luto?. Rio de Janeiro: Civilização Brasileira.

Butler, J. (2015b). Relatar a si mesmo. Belo Horizonte: Autêntica.

Butler, J. (2017). Caminhos divergentes: judaicidade e crítica do sionismo. São Paulo: Boitempo.

Butler, J. (2018). Corpos em aliança e a política das ruas. Notas para uma teoria performativa de assembleia. Rio de Janeiro: Civilização Brasileira.

Carrara, O. V. (2010). Lévinas: do sujeito ético ao sujeito político, elementos para pensar a política outramente. São Paulo: Ideias \& Letras.

Derrida, J. (2001). Mal de arquivo: uma impressão freudiana. Rio de Janeiro: Relume Dumará.

Derrida, J. (2008). As mortes de Roland Barthes. RBSE - Revista Brasileira de Sociologia da Emoção, 7(20): 264-336.

Didi-Huberman, G. (2008). Cuando las imágenes tomam posición. El ojo de la historia, 1. Madrid: A. Machado Libros.

Didi-Huberman, G. (2014). Pueblos expuestos, pueblos figurantes. Buenos Aires: Manantial.

Gagnebin, J. (2000). Palavras para Hurbinek. In A. Nestrovski \& M. Seligmann-Silva (orgs.), Catástrofe e representação (pp. 99-110). São Paulo: Escuta.

Leandro, A. (2016). Os acervos da ditadura na mesa de montagem. LOGOS 45, 23(02): 103-116.

Lévinas, E. (1972). Humanisme de l'Autre Homme. Paris: Fata Morgana.

Lévinas, E. (1980, 1988). Totalidade e infinito. Lisboa: Edições 70.

Lévinas, E. (1984). Die Zeit und der Andere. Hamburgo.

Lévinas, E. (1996). Les Cahiers de la Nuit Surveille. In E. Lévinas, Basic Philosophical Writings (pp. 339-346). Bloomington, Indiana: Indiana University Press.

Lévinas, E. (1997). Quelques réflexions sur la philosophie de l'hitlérisme, suivi d'un essai de Miguel Abensour. Paris: Payot \& Rivages. 
Lévinas, E. (1999a). De otro modo que ser, o más allá de la essência. Salamanca: Ediciones Sígueme.

Lévinas, E. (1999b). Descobrindo a existência com Husserl e Heidegger. Lisboa: Instituto Piaget.

Lévinas, E. (2004). Difícil Libertad: Ensayos sobre el Judaísmo. Madrid: Caparrós Editores.

Lévinas, E. (2007). Ética e infinito. Lisboa: Edições 70.

Lévinas, E. (2010). Entre nós: ensaios sobre a alteridade. Petrópolis: Vozes.

Lévinas, E. (2011). De outro modo que ser ou para lá da essência. Lisboa: Centro de Filosofia da Universidade de Lisboa.

Lévinas, E. (2014). Violência do rosto. São Paulo: Edições Loyola.

Lévinas, E. (2009). Humanismo do outro Homem. Petrópolis: Vozes.

Vieira, F. \& Marques, A. C. S. (2016). Rosto e cena de dissenso: aspectos éticos, estéticos e comunicacionais de constituição do sujeito político. Questões Transversais - Revista de Epistemologias da Comunicação, 4: 17-27. 